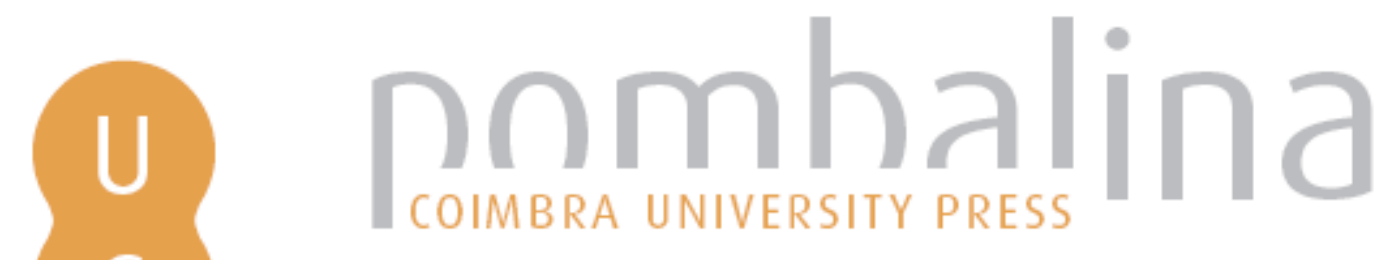

\title{
Motivating Discouraged Youth in Times of Social Change
}

Autor(es): $\quad$ Ferreira, Joaquim Armando; Santos, Eduardo

Publicado por: Imprensa da Universidade de Coimbra

URL

persistente: URI:http://hdl.handle.net/10316.2/43656

DOI: $\quad$ DOl:https://doi.org/10.14195/978-989-26-1451-9_9

Accessed : $\quad$ 26-Apr-2023 14:40:57

A navegação consulta e descarregamento dos títulos inseridos nas Bibliotecas Digitais UC Digitalis, UC Pombalina e UC Impactum, pressupõem a aceitação plena e sem reservas dos Termos e Condições de Uso destas Bibliotecas Digitais, disponíveis em https://digitalis.uc.pt/pt-pt/termos.

Conforme exposto nos referidos Termos e Condições de Uso, o descarregamento de títulos de acesso restrito requer uma licença válida de autorização devendo o utilizador aceder ao(s) documento(s) a partir de um endereço de IP da instituição detentora da supramencionada licença.

Ao utilizador é apenas permitido o descarregamento para uso pessoal, pelo que o emprego do(s) título(s) descarregado(s) para outro fim, designadamente comercial, carece de autorização do respetivo autor ou editor da obra.

Na medida em que todas as obras da UC Digitalis se encontram protegidas pelo Código do Direito de Autor e Direitos Conexos e demais legislação aplicável, toda a cópia, parcial ou total, deste documento, nos casos em que é legalmente admitida, deverá conter ou fazer-se acompanhar por este aviso.

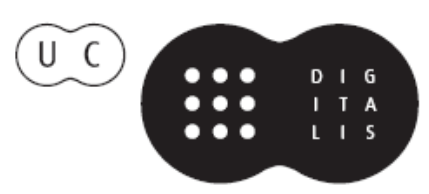


JOAQUIM ARMANDO FERREIRA MATTHIAS REITZLE

EDUARDO SANTOS (EDS.)

\section{CAREER \\ DEVELOPMENT \\ IN CONTEXT}

FESTSCHRIFT FOR

FRED VONDRACEK 


\title{
I X
}

\section{MOTIVATING DISCOURAGED YOUTH IN TIMES OF SOCIAL CHANGE}

\author{
Joaquim Armando Ferreira, University of Coimbra, Portugal; \\ jferreira@fpce.uc.pt \\ Eduardo Santos, University of Coimbra, Portugal; \\ eduardosantos@fpce.uc.pt \\ https://doi.org/10.14195/978-989-26-1451-9_9
}

\begin{abstract}
This chapter presents the rationale and initial planning of a program designed to promote optimal human functioning in discouraged youth attending the 9th grade in a public school in Portugal. Such program can be of utmost relevance as students have to make important educational decisions in the transition from the 9th to the 10th grade. The underlying approach is based on the "Thriving with Social Purpose" (TSP) framework that was developed by M. E. Ford and Smith, inspired on Donald Ford's Living System Framework, which is a holistic and integrative meta-model of behavior and person-in-context functioning.
\end{abstract}

Keywords: Motivational-systemic model, optimal human functioning, vocational decision-making intervention. 


\section{Introduction}

The welcome current focus on an inclusive career counseling (cf. Blustein, 2001, 2006) has served to enhance the desire of career counselors to serve not only middle-class individuals who have a wide variety of options for optimizing their careers, but also to attend to those who are less fortunate and thus socially excluded by virtue of who they are, where they are, or some combination thereof. Thus, a behavioral-political perspective for vocational psychology is needed (Santos \& Ferreira, 1998; Santos, Ferreira, \& Chaves, 2001). This "who-where-combination" focus could be the behavioral matrix of Bronfenbrenner's model (1979) applied to vocational designing, or in other words, the narrative-developmental-person-in-context approach in a phenomenological fashion, which McAdams (1993) proposed occurs trough the interaction between characters and psychosocial stages in the making of personal stories. If one accepts the notion that the large majority of the socially excluded are, in principle, capable of functioning as well as others who are socially included, as part of a negotiation process between client-counselor-social contexts (Vähämöttönen, 1998), it makes sense to address the problem from all vantage points, including (but by no means limited to) a focus on positive development through enhancing individual competence and achievement (Ferreira, Reitzle, Lee, Freitas, Santos, Alcoforado, \& Vondracek, 2015; Vondracek, 1995, 2001; Vondracek \& Lerner, 1982; Vondracek, Lerner, \& Schulenberg,1986; Vondracek, Ferreira, \& Santos, 2010; Vondracek \& Porfeli, 2008; Vondracek, Ford, \& Porfeli, 2014). We could thus envision a broad empowerment strategy leading to "occupational citizenship" (Santos \& Ferreira, 2011), consistent with Hansen's (1997) strength-based approach using appreciative inquiry. 


\section{A developmental-systemic view of vocational behavior and career development}

The purpose of this paper is to present a program designed to promote optimal human functioning in discouraged youth attending the $9^{\text {th }}$ grade in a public school in Portugal. Such program can be of utmost relevance as students have to make important educational decisions in the transition from the $9^{\text {th }}$ to the $10^{\text {th }}$ grade. In many respects, the Adlerian concepts of "courage" and "social interest" (Overholser, 2010), formulated decades ago, addressed worries similar to those faced by today's youth in their life planning! To effectively address these concerns, a possible approach is the "Thriving with Social Purpose" (TSP) framework that was developed by M. E. Ford and Smith (2007). Based on the inspiring paradigm of Donald Ford's Living System Framework (1987), which is a holistic and integrative meta-model of behavior and person-in-context functioning, we could conclude that a teleological model is needed in vocational designing. From genes to memes (Dawkins, 1976), from nature to nurture, from culture to political structures, a true adaptive scheme of reasoning and intervention in vocational psychology is needed for the future. Beyond rationalistic methods we need emotion - driven postures; evolutionary psychology found a social-anthropological basis for this assertion (Martin \& Bateson, 1999; Buss, 2004), and in the neurosciences it is represented by the balance between limbic and cortical systems (Nelson \& Luciana, 2001): a decision is a compromise between cognitive and motivational-emotional variables; as Yalom (1980) states, it is an existential challenge. Otherwise, problems will arise when these dichotomies are not integrated (McGilchrist, 2009). To decide is to implement a dream, and a dream in the gestalt sense is the dreamer (Perls, 
Hefferline, \& Goodman, 1976); so, we could also envisage the decision as the decider!

In accordance with the previous reflections, the conceptual foundation of TSP is represented by Motivational Systems Theory (MST), first presented by M. E. Ford in 1992 and applied to adolescent vocational development by Vondracek and Kawasaki (1995). The basic idea in MST is that there are three sets of psychological processes that make up the concept of motivation: personal goals; personal agency beliefs (made up of capability beliefs and context beliefs); and emotions. These processes work together in cognitive-emotional patterns designed to help people imagine future possibilities and decide whether to pursue or try to avoid those imagined futures. It should be recognized however, that "effective functioning" or "optimal functioning" also requires knowledge and skills, a responsive environment (i.e., a nurturing culture), and supportive biological functioning (M. E. Ford \& Smith, 2007, p. 156). Accordingly, we could use the metaphor that we are a "tool-box" of instrumental bio-psycho-social devices operating in a nurturing system and teleologically driven by personal goals and beliefs, energized by motivational-emotional functional structures.

The basic idea behind Ford and Smith's concept of optimal functioning is that it can be promoted by enhancing or reconfiguring the person-in-context system in such a way as to transform motivational patterns (Figure 1) that are developmentally limiting and effective for only a limited range of goals and contexts into motivational patterns that generatively fuel exploration and competence development, and are thus effective for a much broader range of goals and contexts (M. E. Ford \& Smith, 2007, p. 160). Optimal human functioning can be promoted in multiple ways, including facilitating gains in knowledge and skills and making meaningful improvements in 
the available opportunities and resources. However, the most efficient and powerful pathway to optimal human functioning, according to M. E. Ford (1992), is through the integrated amplification of personal goals, emotions, and personal agency beliefs. From the cell level to consciousness, we know today that a simple relational or dialectical approach to development of life is not enough to explain and promote growth. Finally, and as just another example, chaos theory applied to psychology suggests that behavior is a complex process of co-construction, where different systems potentiate each other in a spiral of life development (Robertson \& Combs, 1995). In sum, we are talking about "behavioral enrichment", in this case, vocational enrichment!

It is our intention to enhance capability and context beliefs through school, family, and community engagement of discouraged youth, using action-reflexion-action processes and techniques, within a person-context framework; these processes and techniques are closely related to neurolinguistic programming (NLP) (Bandler \& Grinder, 1981), in which on a "here-and-now" basis, grounded on subjective experiences, a cognitive-emotional reframing is attempted. The theoretical foundations and the preliminary design of the program will be presented. In accordance with the previous assumptions, it is our vision that a person as a system when acting, and subsequently reflecting over the actions is, in Varela's sense (Froese \& Di Paolo, 2011), transitioning to a $2^{\text {nd }}$ level of action that will be the next personal system, which will then prompt to the next cycle. In other words, we need to construct situations of triggering here-and-now vocational behaviors, thoughts and emotions, and merge them into developmental contexts of de-constructing-re-constructing-amplification-enrichment situations (school, family, society, etc.), that at last will produce changes in the personal systems. 
Thus, this process will lead at a first level to the construction of affective heuristics, and secondly to decisional algorithms, i.e., paths to career decision-making and problem solving among the "clients" to whom this program is directed.

By the cognitive reframing of career goals (development and clarifying) and the mindful coping with the related emotions (investment in positive affects) it is possible to construct career self-efficacy beliefs nested in secure-basis contextual systems.

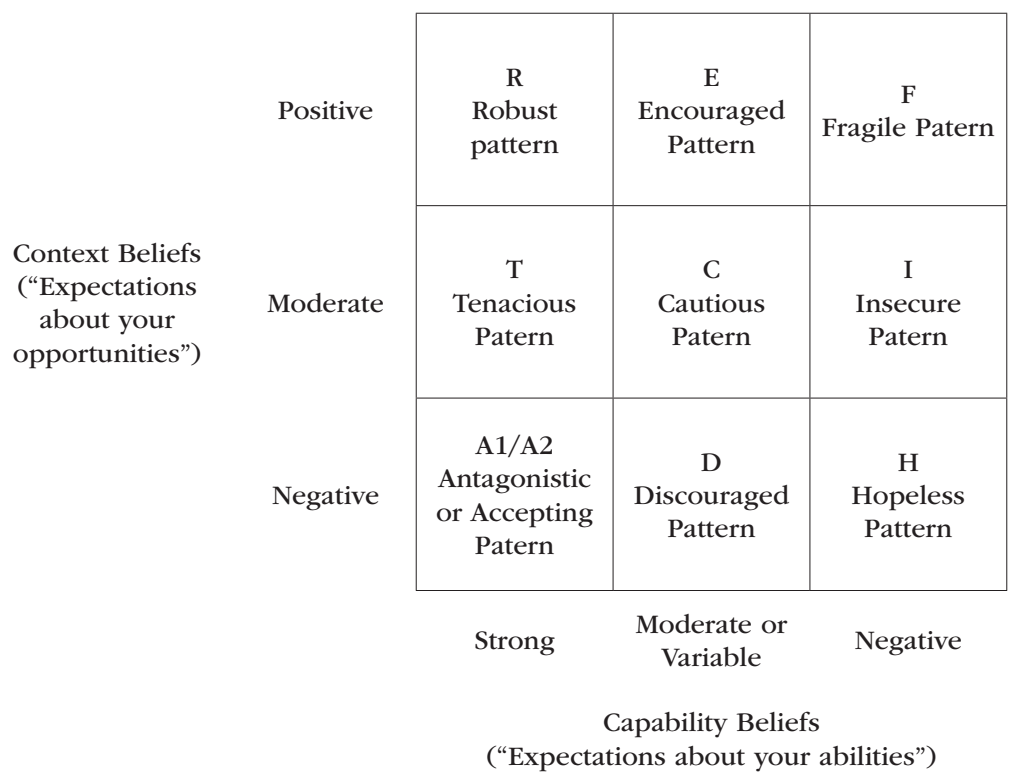

FIGURE 1: Taxonomy of personal agency beliefs patterns (Adapted from Ford \& Smith, 1997, p. 159)

\section{Preliminary description of a vocational designing program}

In order to accomplish these conceptual intentions in pragmatic terms, we are developing a program that will be synthetically presented next, in the following outline: 


\section{Rationale}

Represented by Figure 1, briefly, the rationale of the program is structured as a flow of psychosocial processes and behavioral outcomes, which will be the conceptual basis of the activities/tasks of the intervention program. The model pretends to constitute a meta-framework within psychosocial processes of transitions.

From left to right ("past to future"), first we consider that at the first moment of intervention we have to consider each subject within his/her contextual-developmental history inputs (which must be assessed by the counselor as a primary hermeneutical context). The person's history is the key to his or her Implicit Self (IS), which is organized by three parts, and particularly their reciprocal interactions: Personal Goals (PG), Personal Agency Beliefs (B) and Emotions (E) (Ford's model), operating at the conscious/symbolic (CS) level and/ or the unconscious/imaginary (UCS) level, to different degrees (above or down the line). Emotions relating to PG and B are represented as moving ahead, as its functional etymology shows us: e-motion (moving forward), contrasting with the structural characteristics of PG and B. At IS, we consider also L (latent variables, e.g., interests, spirituality, attachment, information processing...), as a "deepening point" that must be considered in other approaches/situations. Inside each part of IS, as in other parts of the diagram, a $2^{\text {nd }}$ order "molecule" $\left(2^{\text {nd }}\right)$ is present (cf. further explanation).

The emotional dynamics (E) (cf. below in the description of the program), central to IS, create Motivational Patterns (MP) (cf. Vondracek, Ferreira, \& Santos, 2010) which carry the throughputs from IS to the Explicit Self (ES), which is in its turn the sum of the outputs from the Decisional Algorithms 
(DA) (cf. below in the description of the program), as symbolic representations of mind/behavior. This process of connection is modulated by the affective heuristics (AH) (cf. below in the description of the program), which "mirrors" IS to DA, mediated by all the possible loops of feedback and forward, but directly energized by MP, as the anchor point of the flow, from inputs to outputs (throughputs) (cf. Weiner, 1992).

PG, B, L, E, MP, AH, DA are embedded in a $1^{\text {st }}$ order complex system, PsychoSocial Reality system (PSR), which is a dynamic gestalt of the interaction of each of the previous parts, and filled with their connections, and the spread of the outputs from DA, summed with other systems (family, school, community...).

PSR is on its side encapsulated in a $2^{\text {nd }}$ Order Reality system (2ndOR), constituted by the constructionist reframing of PSR that occurs "every second" in a spiral loop between the two, following "autopoetic" laws (cf. Mingers, 1994). This spiral has cognitive and emotional components, and 2 ndOR projects "nano" psychological components/"molecules" $\left(2^{\text {nd }}\right)$ in each of the parts of the psychological-behavioral scheme, modulating its structure and function every time changes occur; these components act as holograms in a fractal process (cf. Gleick, 1987).

In what concerns the Counselor (C), he/she acts as a "helping character", in a NLP fashion, catalyzing the transformational dynamics played between PSR and 2ndOR systems, in a true psychotherapeutic work, intentionally focused in the amplification of the MP (by means of "manipulating" IS and ES), the core/central dimension of the encouragement of youngsters (and other individuals).

Finally, the scheme arrives at a $\mathrm{V}$ point: opening to "Virtual reality", i.e., the possible "editings" which, in a narrative way (Sarbin, 1986), could result in revisions of this representation and subsequent enactions made by individuals/counselors. 


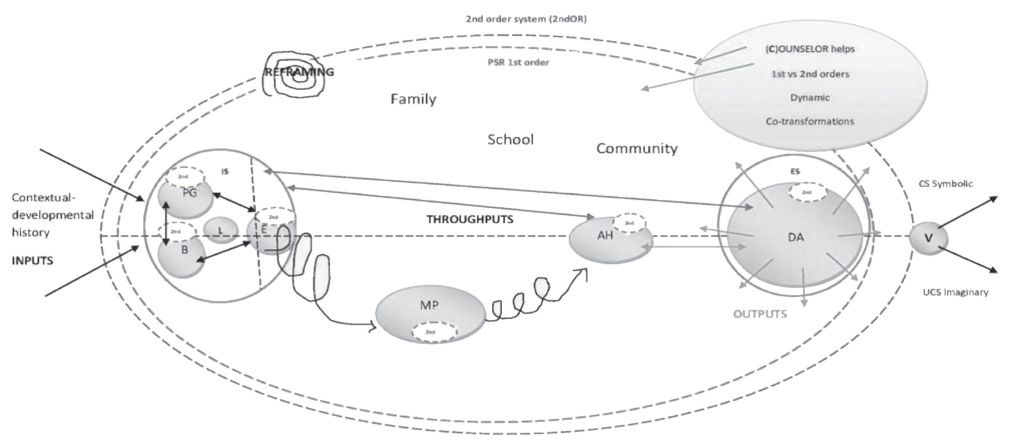

FIGURE 2: Motivational-systemic model of psychosocial activation and decision-making

\section{Program}

Global rationale: a "cascade" of activities from the inner self to behavioral expression of decision making outcomes.

Indoor group sessions with the counselor.

Outdoor activities with family, peers and community (registered in a portfolio).

Role of the counselor: mediator in the Vygotskyan sense, using group dynamics to stimulate behaviors in the indoor sessions, and having as transactional material "vocational cardsorts" (explained ahead), in a 4 step process:

1. Presentation of the activity/metaphor of each session, and $1^{\text {st }}$ processing from the adolescent of the tasks outputs.

2. Processing of the adolescents' outputby the counselor (feedback), having as background the conceptual context for each session.

3. Reprocessing from the adolescents ( $2^{\text {nd }}$ order moment), within different follow-up tasks. 
4. Consolidation of the activities by outdoor tasks registered in the portfolio.

Indoor sessions $(90 \mathrm{~min}$.

1. Start-up and pre-test (assessment using a psychological battery)

2. The Implicit Self/Personal Goals:

Rationale: Ford's Assessment of Personal Goals (APG)

Activity: "The Aladdin lamp"

Task procedures: stimulate vocational "wishes" written in cards; feed-back from counselor; reprocessing of wishes after group discussion written in cards that should be showed to the group as pins.

Counselor behavior: present the metaphor of the activity; hermeneutic posture, feed-back.

Goals: develop and clarify meaningful career goals (personal and social), from wish to pragmatics; at least, it is expected that adolescents will strengthen their self-concepts (Super, 1988).

Portfolio activities: collect and register evaluations of the pins from family and peers.

3. The Implicit Self/Beliefs (in detail ahead):

Rationale: Ford's Personal Agency Beliefs (PAB; cf. Figure 2)

Activity: "Back to the Future"

Task procedures: stimulate vocational self-efficacy beliefs written in cards; feed-back from counselor; reprocessing of personal agency beliefs after group discussion written in cards that should be showed to the group as pins. 
Counselor behavior: present the metaphor of the activity, hermeneutic posture, feedback.

Goals: to work self-efficacy and context-efficacy beliefs (cf. Lent \& Hackett, 1987).

Portfolio activities: replicate and register the activity with peers.

4. Integrating Emotions I (using Tomkins, 1984 model as a possible conceptual framework):

Rationale: using a two axis valence - arousal paradigm adolescents are challenged to point out the main emotions related to the future.

Activity: "The Beauty and the Beast"

Task procedures: after being exposed to the adopted emotions model, point out in two axis cards (valence vs. arousal) each of the emotions related to his/her future.

Counselor behavior: present the metaphor of the activity, hermeneutic posture, feedback.

Goals: mindful coping with the emotions aroused by the planning of the vocational future, and the systems where people will be embedded.

Portfolio activities: collect images illustrative of their emotions, and stamp "smiley's (SAM's) on it.

5. Motivational patterns (using Vondracek, Ferreira, \& Santos, 2010 model):

Rationale: using a puzzle the adolescents are confronted with the complexity of being motivated regarding their futures. Activity: "Puzzle"

Task procedures: after being exposed to the adopted motivational model, organize a face-reverse "puzzle", where each 
piece has on the face a motivational pattern, and in the reverse adolescents should write how each applies to him/herself.

Counselor behavior: present the metaphor of the activity, hermeneutic posture, feedback.

Goals: stimulate self-consciousness of the complexity of motivational patterns, and identity/career styles, directed to the construction of a wise and energized vocational gestalt (Marco, Hartung, Newman, \& Parr, 2003).

Portfolio activities: identify and register in the community (media, heroes, others...) persons who match the different motivational patterns.

6/7. Integrating Emotions II/Affective heuristics (using Kahneman, Slovic, \& Tversky, 1982 model as a possible conceptual framework):

Rationale: in these two sessions' activity, adolescents begin the first moment of integration of the previous activities around the balance of cognitive and emotional processes. Activity: "Salt \& Pepper"

Task procedures: after being exposed to the adopted decisional model, participants are given 4 window-cards (reasoning, sensing, feeling and imagery) where they have to state in each their thoughts about the future, using the different "channels" of mind (cf. Gallegos, 1992). At the end, they have to choose the window that is most likely to be considered as the basis for his/her decision.

Counselor behavior: present the metaphor of the activity, hermeneutic posture, feed-back.

Goals: identify and activate the positive emotions involved in the decision-making processes - from biases to true thoughts. 
Portfolio activities: experiment in everyday life activities to use the different decisional heuristics and register the behavioral consequences.

8/9/10. The Explicit Self/Decisional algorithms (Kasabov, 2002):

Rationale: in these three sessions' activity, adolescents have to "symbolize" in a logical discourse their goals, beliefs, motivations, emotions, thoughts... regarding their personal/social future. They have to act as "mathematicians"!

Activity: "E=mc2"

Task procedures: after being exposed to the session metaphor, participants begin to write down formulas of how they would represent the "laws" that will command their future lives. At the end of the two first sessions, the cards with the formulas are distributed randomly to each of the participants, who have to "criticize" in their portfolios the produced work, and give feedback in the next session.

Counselor behavior: present the metaphor of the activity, hermeneutic posture, feedback.

Goals: produce oral and written career statements, inspired by the logic of algorithms applied to vocational psychology (Gati \& Amir, 2010). A metaphorical "if-then" integration of all activities of the program is expected to result as a phenomenological equation applied to the vocational decision-making process, within a developmental-contextual TSP perspective.

Portfolio activities: see task procedures.

11. Termination and post-test. 


\section{Example of an indoor activity:}

The Implicit Self/Beliefs

Rationale: Ford's Personal Agency Beliefs (PAB; cf. Figure 1) Activity: "Back to the Future"

Task procedures: 1 ) the student is in a first moment invited to talk about his/her expectations regarding the future, and then 2) write on a card a synthesis of it ( $1^{\text {st }}$ message). 3) The counselor analyses the cards and offers one card to the students of the A to $\mathrm{T}$ set of patterns (see above) in function of the content of the $1^{\text {st }}$ message (systemic vocational enrichment). 4) After, each student is invited again to speak, now trying to reframe what was written in his/ her first card, after having reflected on the content of the counselor's card. Finally, the students should write a $2^{\text {nd }}$ message in a new card/pin, about the same topic (at the end students have 3 cards).

Counselor behavior: hermeneutic posture, feedback.

Goals: to work self-efficacy and context-efficacy beliefs (cf. Lent \& Hackett, 1987).

Portfolio activities: this activity has an outdoor follow-up task to be reported in the individual portfolio of reflexions/actions. Using the Altruism therapeutic factor (Yalom, 1995), the youngsters have to target peers who voluntarily will cooperate in the replication of the activity done by each adolescent of the group, now acting as a "counselor"; this "mirroring" activity will consolidate the indoor activity, and it is expected to stimulate the social consciousness of the "brotherhood" of vocational problems, and the need to contextualize all of our activities as a way to seed helping/ developmental scenarios. 


\section{Conclusion}

This vocational enrichment program has as title in Portuguese language: "NÓS", that is simultaneously, WE and KNOTS, in

the Borromean/Lacanian sense of the ties that link the Real, the Symbolic and the Imaginary in the making of our identities (Lacan, 1977). It represents the language metaphor of the person in context reciprocal evolution as a $2^{\text {nd }}$ order reality.

It is expected that the goals of enhancing capability and context beliefs, within the larger intentions of this program, will be attained as a path to motivate discouraged youth along their personal and social road of development.

But to confirm it, there is a need of establishing evaluation procedures of the efficacy of this program. First, we plan a pre-post test single subject design evaluation, directed to the exploration of latent growth curves (McArdle \& Nesselroade, 2003). Secondly, we will implement an experimental design (Spokane, Meir \& Catalano, 2000) to test session by session changes in vocational behaviors, using 3 groups: experimental, control, and placebo.

Finally, considering the metaphorical weight of this program (close to NLP), the language of interrelatedness will be effective only by virtue of systemic reasoning (Olds, 1992).

\section{References}

Bandler, R., \& Grinder, J. (1981). Reframing: Neuro-Linguistic Programming and the Transformation of Meaning. Boulder, CL: Real People Press.

Blustein, D. L. (2001). Extending the reach of vocational psychology: Towardan inclusive and integrative psychology of working. Journal of Vocational Behavior, 59 (2), 171-182.

Blustein, D. L. (2006). The psychology of working: A new persective for career development, counseling and public policy. Mahwah, NJ: Lawrence Erlbaum Associates. 
Bronfenbrenner, U. (1979). The Ecology of Human Development: Experiments by Nature and Design. Cambridge, MA: Harvard University Press.

Buss, D. M. (2004). Evolutionary psychology: the new science of the mind. Boston: Pearson.

Dawkins, R. (1976). The Selfish Gene. New York City: Oxford University Press.

Ferreira, J. A., Reitzle, M., Lee, B., Freitas, R. A., Santos, E., Alcoforado, L. \& Vondracek, F. W. (2015). Configurations of unemployment, reemployment, and psychological well-being: A longitudinal study of unemployed individuals in Portugal. Journal of Vocational Behavior, 91, 54-64. doi: https://doi. org/10.1016/j.jvb.2015.09.004

Ford, D. H. (1987). Humans as self-constructing living systems: A developmental perspective on behavior and personality. Hillsdale, NJ: Erlbaum.

Ford, M. E. (1992). Motivating humans: Goals, emotions, and personal agency beliefs. Newbury Park, CA: Sage.

Ford, M. E., \& Smith, P.R. (2007). Thriving with social purpose: An integrative approach to the development of optimal functioning. Educational Psychologist, 42, 153-171.

Froese, T., \& Di Paolo, E. A. (2011). The Enactive Approach: Theoretical Sketches From Cell to Society. Pragmatics \& Cognition, 19 (1), 1-36.

Gallegos, E. S. (1992). The Animals of the Four Windows: Integrating Thinking, Sensing, Feeling and Imagery. Velarde, NM: Moon Bear Press.

Gati, I., \& Amir, T. (2010). Applying a systematic procedure to locate career decision-making difficulties. Career Development Quarterly, 76, 301-320.

Hansen, L. S. (1997). Integrative Life Planning: Critical Tasks for Career Development and Changing Life Patterns. San Francisco: Jossey-Bass.

Kahneman, D., Slovic, P., \& Tversky, A. (1982). Judgment Under Uncertainty: Heuristics and Biases. New York: Cambridge University Press.

Kasabov, N. (2002). Evolving connectionist systems: Methods and applications in bioinformatics, brain study and intelligent machines. Springer: London.

Lacan, J. (977). Écrits: A Selection (Trans. Alan Sheridan). London: Tavistock Publications.

Lent. R. W., \& Hackett, G. (1987). Career self-efficacy: Empirical status and future directions. Journal of Vocational Behavior, 30, 3, 347-382.

Marco, C. D., Hartung, P. J., Newman, I., \& Parr, P. (2003). Validity of the decisional process inventory. Journal of Vocational Behavior, 63, 1, 1-19.

Martin, P., \& Bateson, P. (1999). Design for a life: How behaviour develops. London: Jonathan Cape.

McAdams, D. (1993). The Stories We Live By: personal myths and the making of the self. New York: Guilford.

McArdle, J.J., \& Nesselroade J.R. (2003). Growth curve analysis in contemporary psychological research. In John A. Schinka \& Waye F. Velicer (Eds). Handbook of psychology: Research methods in psychology (Vol. 2, pp. 447-480). New York, NY: John Wiley \& Sons. 
McGilchrist, I. (2009). The Master and his Emissary: The Divided Brain and the Making of the Western World. New Haven, CT: Yale University Press.

Nelson, C.A., \& Luciana, M. (Eds) (2001). Handbook of Developmental Cognitive Neuroscience. Cambridge, MA: MIT Press.

Olds, L. E. (1992). Metaphors of interrelatedness: Toward a systems theory of psychology. Albany, NY: State University of New York Press.

Overholser, J. C. (2010). Psychotherapy that strives to encourage social interest: A simulated interview with Alfred Adler. Journal of Psychotherapy Integration, Vol 20 (4), Dec., 347-363.

Perls, F.S., Hefferline, R.F., \& Goodman, P. (1976). Gestalt Therapy: Excitement and Growth in the Human Personality. Harmondsworth, Middx.: Penguin.

Robertson, R., \& Combs, A. (Eds.) (1995) Chaos Theory in Psychology and the Life Sciences. Hillsdale, NJ: Lawrence Erlbaum Associates.

Santos, E., \& Ferreira J. A. (2011), "Beyond unemployment: Conceptual and methodological trends", Symposium: Toward new understandings and practices in the psychology of unemployment, at $12^{\text {th }}$ European Congress of Psychology, 4-8 July, Istanbul, Turkey.

Santos, E., \& Ferreira, J. A. (1998). Career Counseling and Vocational Psychology in Portugal: A Political Perspective. Journal of Vocational Behavior, 52, 312-322.

Santos, E., Ferreira, J. A., \& Chaves, A. (2001). Implications of Sociopolitical Context for Career Service Delivery. The Career Development Quarterly, Vol. 50, 1, 45-55.

Spokane, A. T., Meir, E. I., \& Catalano, M. (2000). Person-Environment Congruence and Holland's Theory: A Review and Reconsideration. Journal of Vocational Behavior, 57, 137-187.

Super, D. E. (1988). Vocational adjustment: Implementing a self-concept. The Career Development Quarterly, Vol 36 (4), Jun., 351-357.

Tomkins, S. S. (1984). Affect theory. In K. R. Scherer \& P. Ekman (Eds.), Approaches to emotion (pp. 163-195). Hillsdale, NJ: Erlbaum.

Vähämöttönen, T. (1998). Reframing career counselling in terms of counsellorclient negotiations. An interpretative study of career counselling concepts and practice. Joensuu, Finland: University of Joensuu Publications in Social Sciences, 34 .

Vondracek, F. W. (1995). Vocational identity across the life-span: A developmentalcontextual perspective on achieving self-realization through vocational careers. Man and Work, 6, 85-93.

Vondracek, F. W. (2001). The developmental perspective in vocational psychology. Journal of Vocational Behavior, 59, 252-261.

Vondracek, F. W., \& Kawasaki, T. (1995). Toward a comprehensive framework for adult career development theory and intervention. In W. B. Walsh \& S. H. Osipow (Eds.), Handbook of vocational psychology (2 ${ }^{\text {nd }}$ ed., pp. 111141). Hillsdale, NJ: Lawrence Erlbaum Associates.

Vondracek, F. W., \& Lerner, R. M. (1982). Vocational role development in adolescence. In B. Wolman (Ed.), Handbook of developmental psychology (pp. 602-614). Englewood Cliffs, NJ: Prentice Hall. 
Vondracek, F. W., \& Porfeli, E. J. (2008). Social contexts for career guidance throughout the world: Developmental-contextual perspectives on career cross the lifespan. In J. A. Athanasou \& R. van Esbroeck (Eds.), International handbook of career guidance (pp. 209-225). New York: Springer Publishing.

Vondracek, F. W., Ford, D. H., \& Porfeli, E. J. (2014). A living systems theory of vocational behavior and development. Rotterdam: Sense Publishers.

Vondracek, F. W., Ferreira, J. A., \& Santos, E. (2010). Vocational Behavior and Development in Times of Social Change: New Perspectives for Theory, Research, and Practice. International Journal for Educational and Vocational Guidance, Volume 10, Number 2, 125-138.

Vondracek, F. W., Lerner, R. M., \& Schulenberg, J. E. (1986). Career development: A life-span developmental approach. London: Lawrence Erlbaum.

Yalom, I. D. (1980). Existential psychotherapy. New York: Basic Books.

Yalom, I. D. (1995). Theory and practice of group psychotherapy (4th ed.). New York: Basic Books. 